\title{
Sistem Informasi Perpustakaan Pesantren menggunakan Framework Laravel \\ (Studi Kasus Pada Pondok Pesantren Luhur Wahid Hasyim Semarang(PPLWH Putri))
}

\author{
Izzatul Maghfiroh $^{1^{*}}$, Arief Hidayat ${ }^{2}$ \\ Jurusan Teknik Informatika, Fakultas Teknik, Universitas Wahid Hasyim \\ Jl. Menoreh Tengah X/22, Sampangan, Semarang 50236. \\ *Email: izzamfiroh@gmail.com
}

\begin{abstract}
Abstrak
Pondok Pesantren Luhur Wahid Hasyim Putri adalah salah satu pondok yang menyediakan berbagai fasilitas, salah satunya yaitu perpustakaan. Pencarian koleksi buku yang belum tentu tersedia atau tidak di perpustakaan tersebut menjadi sebuah kendala bagi petugas perpustakaan dan calon peminjam buku. Pencatatan proses peminjaman dan pengembalian buku masih di buku besar sehingga meyulitkan petugas perpustakaan ketika ingin mencari data yang diiinginkan. Penelitian ini bertujuan menghasilkan sebuah sistem perpustakaan berbasis web yang dapat memudahkan calon peminjam melihat ketersediaan buku di perpustakaan dan membantu petugas perpustakaan mengelola data peminjaman dan pengembalian buku secara efektif dan efisien. Metode pengembangan sistem yang digunakan yaitu waterfall yang memiliki tahapan analisis, desain, pengodean, pengujian. Hasil penelitian ini yaitu sebuah sistem informasi perpustakaan pada PPLWH Putri yang dapat mengelola data buku, data transaksi dan data laporan, dan untuk perbedaan sistem informasi perpustakaan dari sistem informasi perpustakaan yang lain ialah terdapat fitur notifikasi pesan kepada peminjam mengenai waktu pengembalian yang sudah jatuh tempo menggunakan whatsapp yang dilakukan oleh petugas perpustakaan
\end{abstract}

Kata kunci: Perpustakaan, PPLWH Putri, Sistem informasi, Waterfall

\section{PENDAHULUAN}

Perkembangan teknologi informasi dan komunikasi yang cepat dalam dunia ini membuat banyak orang sadar akan pentingnya informasi. Media informasi dan telekomunikasi merupakan media yang dapat digunakan dalam proses transaksi informasi. Dengan adanya teknologi informasi dan telekomunikasi yang berkembang pesat di dunia perpustakaan membuat perpustakaan menggunakan teknologi dalam proses kegiatannya.

Pengetahuan tidak hanya diperoleh dengan pengalaman secara nyata namun juga didapat dari informasi yang diterima. Informasi dapat dilakukan dengan berbagai media, salah satunya dengan membaca buku yang disediakan di perpustakaan. Hal ini sesuai dengan fungsi perpustakaan yaitu sebagai tempat penyimpanan, mengolah, menyajikan, menyebarluaskan, dan melestarikan pengetahuan. Dalam menjalankan fungsinya, perpustakaan membutuhkan berbagai macam laporan penting yang akan digunakan untuk mengawasi kualitas pelayanan dan ketersediaan koleksi pustaka dalam memenuhi pembutuhan pembelajarannya. Definisi lain menyatakan bahwa perpustakaan berfungsi untuk mengenalkan teknologi informasi (Lasa, 2007:15)

Pondok Pesantren Luhur Wahid Hasyim adalah salah satu pondok yang terletak di daerah Semarang tepatnya di Kelurahan Sampangan. Pondok Pesantren tersebut terdapat banyak fasilitas, salah satunya yaitu perpustakaan yang merupakan salah satu sarana untuk mendapatkan berbagai informasi. Saat ini proses peminjaman dan pengembalian buku di perpustakaan tersebut masih dilakukan secara tertulis ke dalam bentuk buku besar. Begitu pula pada saat pembuatan laporan masih secara tertulis. Di samping itu, pencarian data buku yang belum jelas ada tidaknya di koleksi perpustakaan tersebut akan menjadi sebuah kendala bagi petugas perpustakaan dan calon peminjam buku. Pencatatan proses peminjaman dan pengembalian buku tidak secara up-to-date sehingga beberapa koleksi pustaka banyak yang hilang.

Berdasarkan kondisi tersebut hasil dari rancang bangun sistem informasi perpustakaan 
dapat yang dapat mempermudah santri melihat koleksi pustaka yang dipunyai perpustakaan dan petugas dapat merekap semua transaksi peminjaman maupun pengembalian dalam bentuk laporan.

\section{TINJAUAN PUSTAKA}

Penelitian sejenis sebelumnya pernah dilakukan oleh Perwira (2015) mengenai "Sistem Informasi Perpustakaan Berbasis Web di SMK Muhammadiyah 1 Yogyakarta”. Latar belakang penelitian ini yaitu pengelolaan proses peminjaman dan pengembalian buku perpustakaan dapat memakan banyak biaya dan waktu karena perlu pencatatan oleh siswa yang harus dilakukan secara manual. Metode penelitian yang digunakan adalah Research and Development (R\&D). Model proses pengembangan software digunakan model waterfall. sistem informasi perpustakaan berbasis web dikembangkan menggunakan framework Laravel. Pemanfaatan sistem informasi perpustakaan berbasis web dapat menghemat biaya dan waktu karena proses sudah dilakukan menggunakan komputer.

Penelitian sejenis lainnya juga pernah dilakukan oleh Hakim (2017) mengenai "Sistem Informasi Inventarisi Buku Perpustakaan Jurusan Teknik Elektro Universitas Negeri Semarang". Latar belakang penelitian ini yaitu perpustakaan perguruan tinggi sebagai sarana penunjang pembelajaran di kampus seringkali terkendala oleh keterbatasan informasi buku yang tersedia, buku tidak dikembalikan setelah dipinjam dan laporan kegiatan perpustakaan masih manual dengan buku. jenis penelitian pengembangan (Research and Development) dengan model ADDIE. Sistem informasi inventarisasi buku ini dikembangkan dengan framework laravel. Manfaat dari sistem ini dapat memberikan kemudahan mencari informasi buku yang tersedia.

Kartubi dan Arifin (2019) juga pernah melakukan penelitian mengenai " Sistem Informasi Perpustakaan Berbasis Website Dengan Framework Laravel'. Latar belakangnya yaitu mahasiswa harus datang ke perpustakaan kampus apabila ingin membaca buku atau sekedar mencari materi tugas kuliah, hal ini menimbulkan masalah bagi mahasiswa yang berkuliah sambil bekerja. Metode yang digunakan dalam pembuatan sistem ini ialah
SDLC (System Development Life Cycle). Manfaat dari sistem yaitu mahasiswa dan dosen dapat mengakses informasi mengenai buku kapan dan dimana saja.

Perbedaaan dengan penelitian yang akan dikerjakan yaitu pada sistem informasi perpustakaan pesantren menggunakan framework laravel ini dilengkapi dengan fitur pengiriman pemberitahuan (notifikasi) batas akhir peminjaman buku kepada peminjamnya melalui Whatsapp.

\subsection{Metode Waterfall}

'Model SDLC air terjun (watefall) sering juga disebut model sekuensial linier (sequential liniear) atau alur hidup klasik (classic life cycle). Model air terjun menyediakan pendekatan alur hidup perangkat lunak secara sekuensial atau terurut dimulai dari analisis, desain, pengodean, pengujian (Rosa A.S, 2016).Tahapan tahapan penjelasan dari pemodelan sistem waterfall yaitu (Rosa A.S, 2016).:

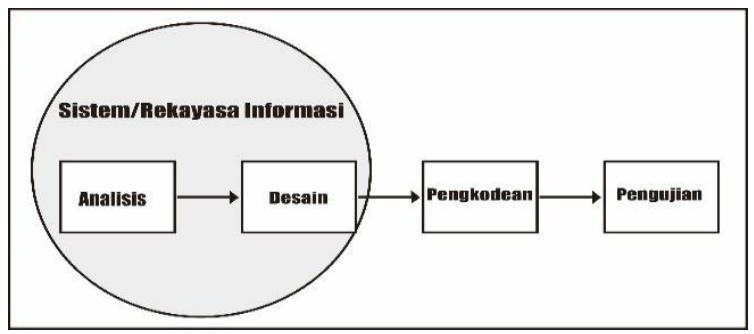

(Sumber: Rosa A.S)

\section{Gambar 1. Metode Pengembangan Waterfall}

a. Analisis kebutuhan perangkat lunak

Proses pengumpulan kebutuhan dilakukan secara intensif untuk mespesifikasikan kebutuhan perangkat lunak agar dapat dipahami perangkat lunak sepeti apa yang dibutuhkan oleh penguna.

b. Desain

Desain perangkat lunak adalah proses multi langkah yang fokus pada desain pembuatan program perangkat lunak termasuk struktur data, arsitektur perangkat lunak, representasi perangkat antar muka, dan prosedur pengodean.

c. Pembuatan kode program

Desain harus ditranslasikan ke dalam program perangkat lunak. 
d. Pengujian

Pengujian fokus pada perangkat lunak secara dari segi logik dan fungsional dan memastikan bahwa semua bagian sudah diuji.

\subsection{Software Pendukung}

Pembuatan sistem informasi perpustakaan pesantren pada PPLWH Putri ini menggunakan software-software pendukung sebagai berikut :

1. Browser Chrome

2. PHP versi 7.0.0

3. Editor Text: Sublime text 3

4. PackageDependency PHP : Composer versi 1.5.2

5. Framework PHP: Laravel versi 5.8

6. Web server : Xampp v3.2.4

7. Database server: $M y S Q L$

8. Pengelola database : phpMyadmin

9. Pemodelan interface : BalsamiqMockup

\section{METODE PENELITIAN}

\subsection{Metode Pengumpulan Data}

Metode pengumpulan data yang digunakan dalam penelitian ini adalah sebagai berikut:

\section{Metode observasi}

Metode ini dilakukan dengan cara mendatangi langsung ke lokasi pondok pesantren luhur wahid hasyim semarang (PPLWH Putri), adapun observasi yang dilakukan:

a. Mengamati proses kegiatan yang berlangsung pada perpustakaan PPLWH Putri, hasil dari pengamatan tersebut ialah terjadi peminjaman buku secara manul yaitu berupa pencatan di buku besar,kemudian terdapat beberapa santri belajar di perpus.

b. Pengambilan informasi secara detail seputar kekurangan yang ada di dalam perpus PPLWH Putri. hasil dari pengambilan informasi kekurangannya ialah belum adanya perpustakaan yang berbasis web, pencarian data buku yang belum jelas ada tidaknya di koleksi perpustakaan tersebut akan menjadi sebuah kendala bagi petugas perpustakaan dan calon peminjam buku, beberapa buku yang hilang karena pihak santri lupa mengembalikan.

\section{Metode wawancara}

Metode ini dilakukan dengan cara peneliti mengumpulkan data secara langsung dengan melakukan komunikasi tanya jawab langsung terhadap pengurus pondok pesantren (lurah) dan departemen perpustakaan meliputi proses kegiatan yang terjadi untuk melengkapi kebutuhan informasi yang akan digunakan dalam pengembangan sistem. Hasil wawancara yaitu mendapatkan informasi kegiatan peminjaman di perpustkaan tersebut beserta data peminjaman buku, data buku perpus PPLWH.

\section{Metode kepustakaan}

Metode ini dilakukan dengan cara mencari dan membaca literatur yang sudah ada. Literatur yang diperoleh berupa jurnal, skripsi, buku, dan artikel terkait dengan sistem informasi perpustakaan pesantren yang akan digunakan untuk penelitian ini.

\section{HASIL DAN PEMBAHASAN \\ 4.1 Hasil}

\subsubsection{Anggota}

1. Pada Gambar 2 merupakan tampilan user bagian login. Untuk mengelola data buku, data anggota, data user, data transaksi dan data laporan, untuk mengakses hal tersebut maka admin login terlebih dahulu.

PERPUSKU PPLWH

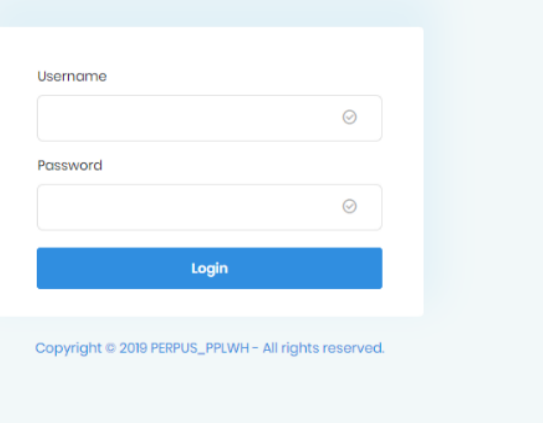

Gambar 2. Tampilan Login

2. Gambar 3 merupakan tampilan menu ketika sudah login. Menu tersebut berupa dosboard, transaksi dan laporan. Gambar dibawah ada gambar menu dosboard yang berisi data data buku yang ada di perpustakaan. dalam hal ini di bagian judul 
buku, user dapat melihat diskripsi dari buku, kemudian user dapat melakukan pesan pinjam atau disebut dengan booking buku sebelum dilakukan peminjaman buku

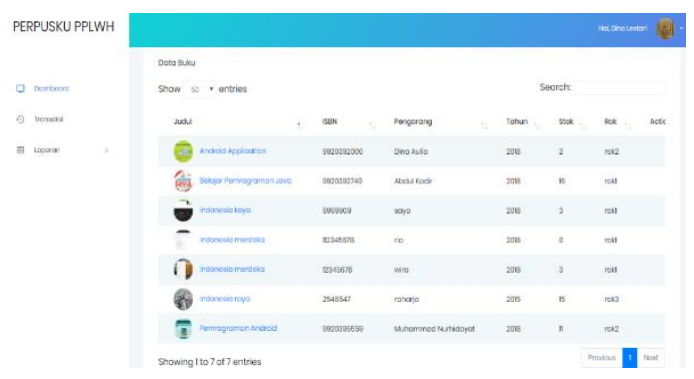

Gambar 3. Tampilan Dasboard

3. Gambar 4 merupakan tampilan menu user bagian transaksi. User dapat melihat data peminjaman maupun data pesan pesan pinjam atau booking buku

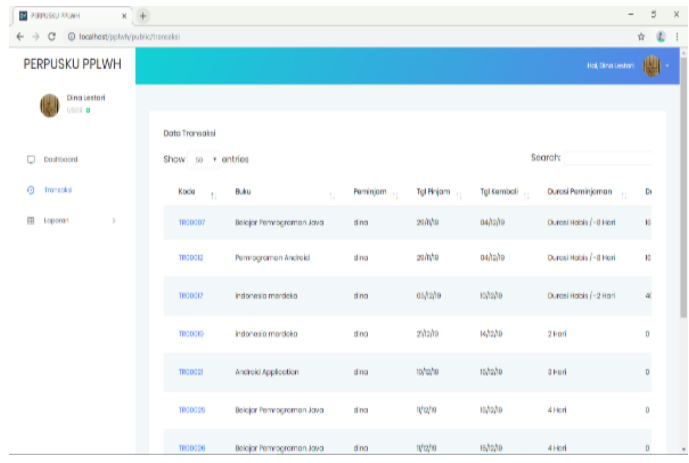

Gambar 4. Tampilan Transaksi

4. Gambar 5 merupakan tampilan menu user bagian transaksi. User dapat mencetak laporan transaksinya sendiri. Baik transaksi pinjam, kembali, atau kategori transaksi semua.

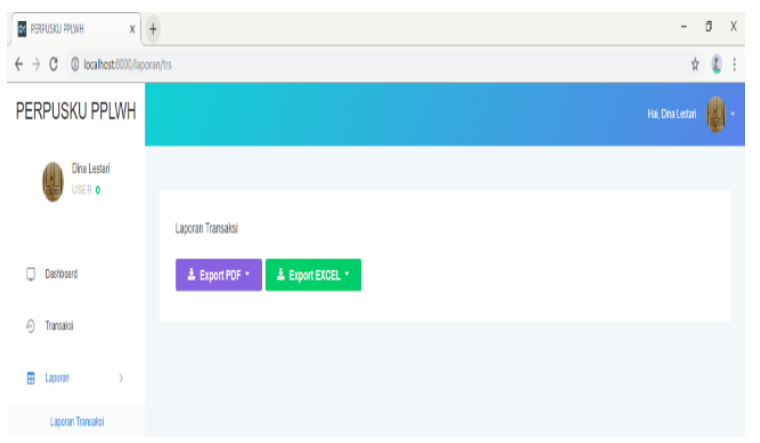

Gambar 5. Laporan Transaksi

\subsubsection{Admin}

1. Gambar 6 merupakan tampilan login admin.

\section{PERPUSKU PPLWH}

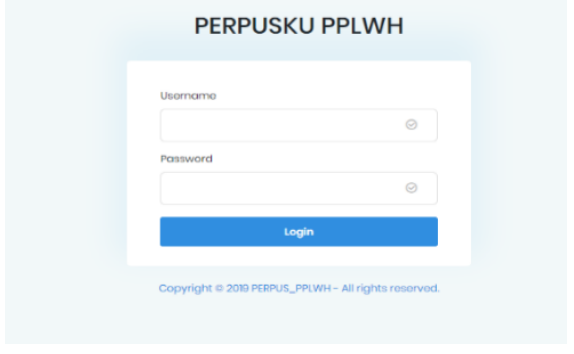

\section{Gambar 6. Tampilan Login Admin}

2. Gambar 7 merupakan tampilan admin bagian halaman utama, yang terdiri dari menu dasboard, master data, transaksi, kemudian laporan. Gambar dibawah ini yaitu menu dasboard yang terdapat data data data buku. Admin dapat menghapus databuku dan edit data buku berupa menambahkan data buku dalam bentuk excel, maupun di edit secara manual.

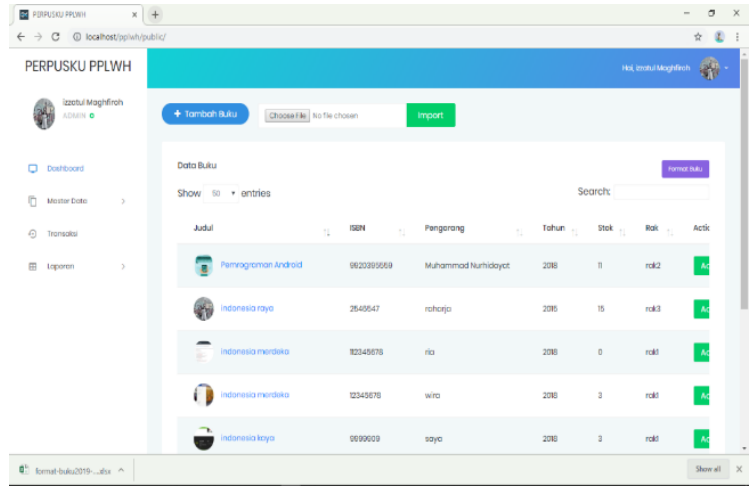

\section{Gambar 7. Tampilan Dasboard}

3. Gambar 8 merupakan tampilan admin pada menu master data. Pada menu master terdiri sub menu yaitu menu data anggota, data buku, data user. Gambar dibwah yaitu sub menu data anggota. Dalam sub menu ini berupa data data anggota yang telah menjadi anggota. Admin dapat menghapus data anggota dan mengedit data anggota apabila terjadi kekeliruan data pada anggota tersebut. 


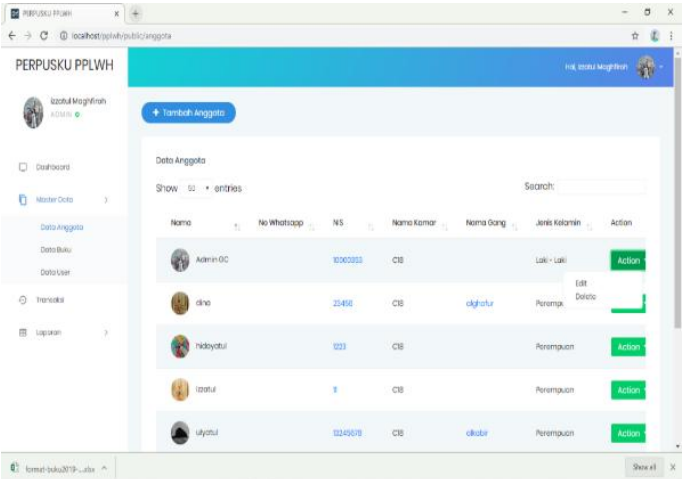

\section{Gambar 8. Tampilan Data Anggota}

4. Gambar 9 merupakan tampilan admin bagian sub menu data buku. Pada sub menu data buku terdiri data data data buku yang ada di perpustakaan. Gambar dibawah ini yaitu menu dasboard yang terdapat data data data buku. Admin dapat menghapus databuku dan edit data buku berupa menambahkan data buku dalam bentuk excel, maupun di edit secara manual.

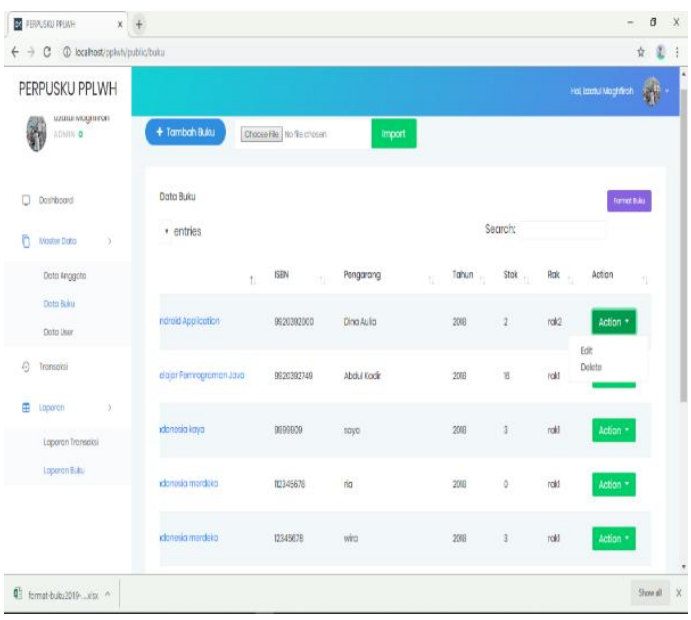

\section{Gambar 9. Tampilan Data Buku}

5. Gambar 10 merupakan tampilan sub menu user. Pada sub menu user terdapat data data user. Pada gambar dibawah ini yaitu admin dapat menambah user dan mengahpus dan mengedit data user. Fungsi dari sub menu data user ialah untuk verifikasi pada menu data anggota ketika menambahkan data anggota dibagian level, ketika sudah menjadi data user maka secara otomatis nama dari pemambahan user akan tertera pada form level yang terdapat pada penambahan data anggota.

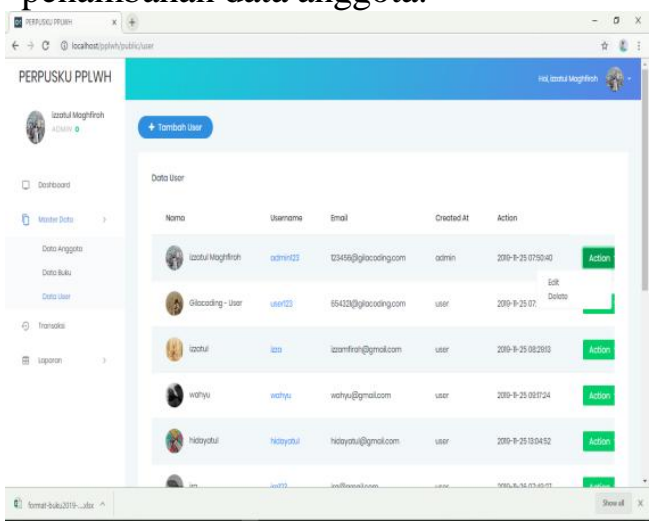

\section{Gambar 10. Data User}

6. Gambar 11 merupakan tampilan admin bagian menu transaksi. Pada menu transaksi terdiri dari data data anggota yang telah meminjam buku. Pada gambar dibawah ini yaitu admin dapat menambahkan data peminjaman buku, menghapus buku yang telah dikembalikan, mengirim notifkasi pengembalian buku, kemudian mencari data data peminjaman, dan melihat data data user yang telah pesan pinjam atau disebut dengan booking buku.

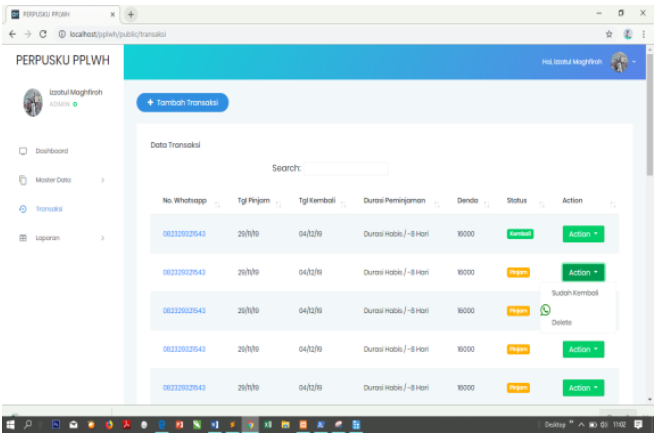

Gambar 11. Tampilan Transaksi

7. Gambar 12 merupakan tampilan menu admin menu laporan. Pada menu laporan terdiri dari sub menu yaitu menu laporan transaksi dan menu laporan buku. Dibawah ini adalah gambar sub menu laporan transaksi berupa pilihan menu, admin dapat melakukan pencetakan laporan transaksi untuk bagian pengembalian dan peminjaman atau semua transaksi. 


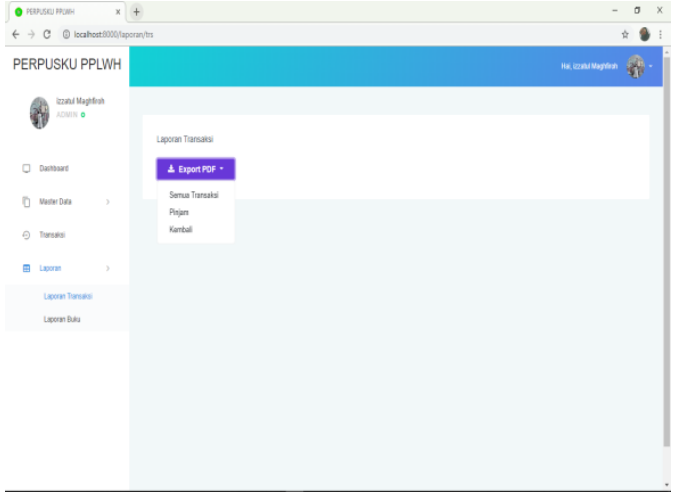

\section{Gambar 12. Tampilan Laporan} Transaksi

8. Gambar 13 merupakan tampilan menu admin menu laporan. Pada menu laporan terdiri dari sub menu yaitu menu laporan transaksi dan menu laporan buku. Dibawah ini adalah gambar sub menu laporan buku berupa pilihan menu, admin dapat melakukan pencetakan laporan buku.

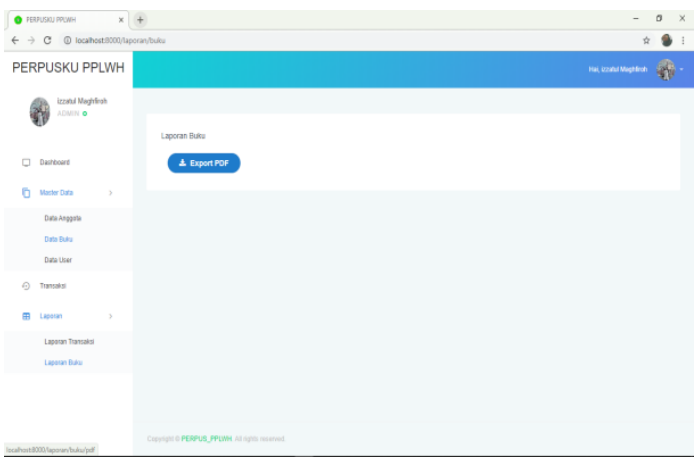

Gambar 13. Tampilan Laporan Buku

\section{KESIMPULAN DAN SARAN \\ 5.1 Kesimpulan}

Berdasarkan hasil penelitian ini, dapat diambil kesimpulan sebagai berikut :

1. Peneliti telah berhasil membuat sistem informasi perpustakaan untuk pondok Pesantren Luhur Wahid Hasyim Semarang. Sistem perpustakaan dapat mengelola data buku, anggota/santri, dan data transaksi peminjaman dan pengembalian. menghasilkan laporan data buku, anggota/santri dan transaksi peminjaman dan pengembalian sehingga mempermudah bagi petugas perpustakaan.

2. Dengan perpustakaan ini memungkinkan anggota untuk mengetahui data buku kemudian anggota dipermudah dengan pesan pinjam atau booking buku yang dapat diakses dengan mudah secara online menggunakan website.

\subsection{Saran}

Adapun saran yang dapat dikemukakan adalah sebagai berikut:

1. Pengembangan sistem informasi perpustakaan ini dengan menambahkan tampilan pengguna secara umum. Supaya tidak hanya anggota yang bisa mengakses data data buku yang tersedia di perpustakaan PPLWH Putri Semarang melainkan masyarakat umum selain santri dari PPLWH Putri Semarang.

2. Sistem informasi perpustakaan berbasis website ini selanjutnya dapat dikembangkan menjadi aplikasi perpustakaan yang memungkinkan santri mendownload aplikasi tersebut.

\section{DAFTAR PUSTAKA}

Hakim Abdul Akhmad, 2017, Sistem Informasi Inventarisasi Buku Perpustakaan Jurusan Teknik Elektro Universitas Negeri Semarang, lib.unnes, Semarang, hal 1-66. Kartubi Ahmad, Arifin Rita Wahyuni. 2019. Sistem Informasi Perpustakaan Berbasis Website Dengan Framework Laravel, ISSN: 2528-6919, Bekasi, hal 213-222.

Lasa, 2007, Manajemen Perpustakaan Sekolah, Pinus, Yogyakarta:

Perwira Nanda Husin. 2015. Pengembangan Sistem Informasi Perpustakaan Berbasis Web Di Smk Muhammadiyah 1 Yogyakarta, eprints.uny, yogyakarta. Hal $1-170$.

Rosa A.S., Shalahuddin M., 2016, Rekayasa Perangkat Lunak, Informatika, Bandung. 